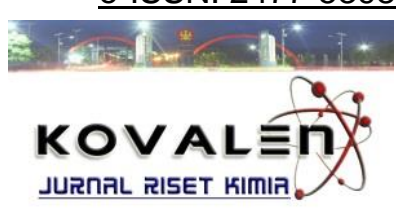

\title{
PENGARUH RASIO PELARUT TERHADAP EKSTRAKSI DARI KULIT BUAH NAGA MERAH (Hylocereus polyrhizus)
}

\section{[The Effect of Solvent Ratio to the Quality of Extracts from the Red Dragon Fruit Peel (Hylocereus polyrhizus)]}

\author{
Amalia Noviyanty $^{1^{\star}}$, Chitra Anggriani Salingkat ${ }^{1}$, Syamsiar ${ }^{1}$ \\ 1) Program Studi Agroteknologi, Fakultas Pertanian, Universitas Tadulako, \\ Jl. Soekarno Hatta Km.9, Palu 94118, Indonesia \\ *Corresponding Author: amalianoviyanti@ymail.com (hp 085241237506) \\ Diterima 25 Oktober 2019, Disetujui 10 Desember 2019
}

\begin{abstract}
This study aims to determine the effect of the ratio of solvents to extract yield, phenolics total and $I_{50}$ values of red dragon fruit peel and also get the optimal solvent ratio to obtain extract yield, phenolics total and the highest or best $\mathrm{IC}_{50}$ values of red dragon fruit peel extracts. The solvent ratio used there are 6 levels of the ratio: $2: 1 ; 3: 1 ; 4: 1 ; 5: 1 ; 6: 1$ and $7: 1(\mathrm{v} / \mathrm{w})$. The data obtained were analyzed using a Completely Randomized Design that was applied to observations of extract yield, phenolics total and $\mathrm{IC}_{50}$ values, if the treatment had a very significant or significant effect followed by continued Tukey HSD test at $1 \%$ or $5 \%$ level. The results showed that the solvent ratio very significantly affected the extract yield, phenolics total and $\mathrm{IC}_{50}$ value of red dragon fruit peel extract. Solvent ratio of $4: 1(\mathrm{v} / \mathrm{w})$ produced extract yield, phenolics total and $\mathrm{IC}_{50}$ values the highest or best i.e $26.22 \%, 71.56 \mathrm{ppm}$ and $124.62 \mathrm{ppm}$.
\end{abstract}

Keywords : $I C_{50}$, the red dragon fruit skin, solvent ratio, phenolics total

\begin{abstract}
ABSTRAK
Penelitian ini bertujuan untuk mengetahui pengaruh rasio pelarut terhadap rendemen ekstrak, total fenolat dan nilai IC50 dari kulit buah naga merah dan juga memperoleh rasio pelarut yang optimum untuk mendapatkan rendemen ekstrak, total fenolat dan nilai $\mathrm{IC}_{50}$ tertinggi atau terbaik untuk mengekstrak kulit buah naga merah. Rasio pelarut yang digunakan ada 6 tingkatan rasio yaitu 2:1; $3: 1 ; 4: 1 ; 5: 1 ; 6: 1$ dan $7: 1$ (v/b). Data yang diperoleh dianalisis menggunakan Rancangan Acak Lengkap yang diterapkan pada pengamatan rendemen ekstrak, total fenolat dan nilai $\mathrm{IC}_{50}$, jika perlakuan berpengaruh sangat nyata atau nyata dilanjutkan uji lanjut BNJ pada taraf $1 \%$ atau $5 \%$. Hasil penelitian menunjukkan bahwa rasio pelarut berpengaruh sangat nyata terhadap rendemen ekstrak, total fenolat dan nilai $I_{50}$ ekstrak kulit buah naga merah. Rasio pelarut $1: 4(\mathrm{~b} / \mathrm{v})$ menghasilkan rendemen ekstrak, total fenolat dan nilai IC ${ }_{50}$ tertinggi atau terbaik yaitu $26,22 \%, 71,56$ ppm dan 124,62 ppm.
\end{abstract}

Kata kunci: $I C_{50}$, kulit buah naga merah, rasio pelarut, total fenolat 


\section{LATAR BELAKANG}

Kulit buah naga selama ini jarang termanfaatkan dan hanya menjadi limbah. Padahal, kulit buah naga juga memiliki kapasitas antioksidan dan efek antiproliferative (Stintzing et al., 2002; Wu, et al., 2006). Persentase kulit buah naga merah adalah 30\% hingga 35\% dari berat buahnya (Santoso dan Fibrianto, 2017). Kulit buah naga merah memiliki kandungan nutrisi seperti karbohidrat, lemak, protein dan serat pangan (Harjanti, 2016). Zat yang terkandung dalam kulit buah naga berdaging merah yaitu dalam $100 \mathrm{~g}$ buah naga, mengandung kalori 60 kkal, protein $0,53 \mathrm{~g}$, karbohidrat $11,5 \mathrm{~g}$, serat $0,71 \mathrm{~g}$, kalsium $134,5 \mathrm{mg}$, fosfor $87 \mathrm{mg}$, zat besi $0,65 \mathrm{mg}$, vitamin C 9,4mg, antosianin, antioksidan, fenolat, flavonoid, protein, lemak, air, karbohidrat, abu, pentacyclictriyepene-taraxast-20-ena-3aol dan taraxast-12,20(30)-dien-3aol, serta kandungan airnya sebanyak 90\% (Handayani dan Rahmawati, 2012). Sehingga kulit buah naga ini berpotensi untuk dikembangkan sebagai bahan pangan fungsional.

Menurut Yuswi (2017) ekstraksi adalah proses untuk memisahkan senyawa aktif yang terkandung dalam tanaman. Salah satu faktor yang mempengaruhi ekstraksi adalah jumlah pelarut yang digunakan (Benedicta et al., 2016). Banyaknya pelarut akan mengurangi tingkat kejenuhan pelarut, sehingga komponen kimia yang terkandung dalam tanaman akan terekstrak secara sempurna (Jayanudin et al., 2014). Semakin tinggi jumlah pelarut yang digunakan, maka pengeluaran senyawa target ke dalam pelarut dapat berjalan lebih optimal dan pelarut mengalami kejenuhan juga dapat dihindari. Akan tetapi, setelah jumlah pelarut dinaikkan dalam jumlah tertentu maka peningkatan rendemen relatif kecil dan cenderung menjadi konstan (Rifai et al., 2018). Rendemen, mutu serta kadar senyawa aktif yang dihasilkan merupakan parameter keberhasilan proses pemurnian suatu ekstrak (Hernani et al., 2007).

Sejauh ini penelitian tentang ekstraksi kulit buah naga telah beberapa kali dilakukan, tetapi belum ditemukan informasi tentang rasio pelarut yang optimum untuk mengekstrak kulit buah naga merah dengan menggunakan pelarut etanol 95\%. Berdasarkan hal tersebut diatas, penelitian ini bertujuan untuk mengetahui pengaruh rasio pelarut terhadap rendemen ekstrak, total fenolat dan nilai $I C_{50}$ pada ekstrak kulit buah naga merah dan juga memperoleh rasio pelarut yang optimum untuk mendapatkan rendemen ekstrak, total fenol dan nilai $\mathrm{IC}_{50}$ tertinggi atau terbaik.

\section{METODE PENELITIAN}

\section{Bahan dan Peralatan}

Bahan utama yang digunakan yaitu kulit buah naga merah yang berasal dari Pasar Tradisional Inpres Manonda, Palu, Sulawesi Tengah. Sedangkan bahan penunjang yang digunakan yaitu etanol 
95\%, asam galat, reagen Folin Ciocalteu, larutan $\mathrm{Na}_{2} \mathrm{CO}_{3} 20 \%$, gas $\mathrm{N}_{2}$, dan larutan DPPH $50 \mu \mathrm{M}$ diperoleh dari laboratorium MIPA Fakultas MIPA Universitas Tadulako, Palu.

Peralatan yang digunakan adalah timbangan biasa, timbangan analitik, kertas saring, blender, penangas air, erlenmeyer, labu ukur alas bulat yang dilengkapi dengan pendingin balik, rotary evaporator, tabung reaksi, mesin pengocok, spektrofotometer UV-Vis (Pelkinelmer), pipet tetes.

\section{Prosedur Penelitian}

\section{Persiapan kulit buah naga merah}

Kulit buah naga merah yang diperoleh diiris, dihaluskan, dkeringkan dan dibuat menjadi tepung dengan menggunakan blender, kemudian siap untuk digunakan pada penelitian selanjutnya.

\section{Ekstraksi kulit buah naga merah}

Tahap ini dilakukan dengan cara kulit buah naga merah bentuk tepung ditimbang sebanyak $50 \mathrm{~g}$, kemudian dimasukkan ke dalam erlenmeyer $500 \mathrm{ml}$, selanjutnya ditambahkan pelarut etanol 95\% sesuai perlakuan yaitu $2: 1 \mathrm{v} / \mathrm{b},(\mathrm{A}), 3$ $: 1 \mathrm{v} / \mathrm{b}(\mathrm{B}), 4: 1 \mathrm{v} / \mathrm{b}(\mathrm{C}), 5: 1 \mathrm{v} / \mathrm{b}(\mathrm{D}), 6: 1$ v/b (E) dan $7: 1 \mathrm{v} / \mathrm{b}(\mathrm{F})$. Campuran dikocok di atas mesin kocok (shaker) aqitasi 200 rpm selama 1 hari (24 jam). Campuran disaring, filtrat atau ekstrak yang dihasilkan diuapkan pelarutnya secara vakum dengan alat rotari vakum evaporator. Penguapan pelarut disempurnakan dengan gas nitrogen. Ekstrak selanjutnya ditimbang untuk mengetahui rendemannya, ditentukan nilai $I_{50}$ dan total fenolatnya. Rasio pelarut yang menghasilkan ekstrak yang memiliki rendemen, total fenolat dan nilai $I_{50}$ tinggi dinyatakan sebagai rasio pelarut terseleksi.

\section{Penentuan Total Fenolat (Folin and Ciocalteu,1944)}

\section{a. Pembuatan Kurva Kalibrasi Asam Galat Dengan Reagen Folin- Ciocalteu.}

Asam galat ditimbang $25 \mathrm{mg}$ dan ditambahkan etanol 96\% : air (1:1) sampai volume $25 \mathrm{ml}$. Dari larutan induk 1000mg/l dibuat seri pengenceran $20,40,60,80$, 100, dan 120 mg/l asam galat. Dari masing-masing konsentrasi di atas dipipet $1 \mathrm{ml}$ dan ditambahkan $10 \mathrm{ml}$ aquadest, kemudian ditambah $1 \mathrm{ml}$ Reagen Folin Ciocalteu dan dikocok. Larutan didiamkan selama 8 menit, ditambahkan $3 \mathrm{ml}$ larutan $\mathrm{Na}_{2} \mathrm{CO}_{3} \quad 20 \%$, dikocok homogen. Didiamkan selama 2 jam pada suhu kamar. Diukur serapan pada panjang gelombang maksimum yang diperoleh, kemudian dibuat kurva kalibrasi hubungan antara konsentrasi asam galat (mg/l) dengan absorban.

\section{b. Penentuan Kandungan Total Fenolik dengan Metode Folin Ciocalteu.}

Ekstrak pekat ditimbang $0,025 \mathrm{mg}$ dan dilarutkan sampai $25 \mathrm{ml}$ dengan etanol : air (1:1). Larutan dipipet $1 \mathrm{ml}$, ditambah dengan $10 \mathrm{ml}$ aquadest dan 1 $\mathrm{ml}$ reagen Folin Ciocalteu dan dikocok. 
Larutan didiamkan selama 8 menit, ditambah $3 \mathrm{ml} \mathrm{Na2CO} 3$ 20\%, kemudian didiamkan selama 2 jam pada suhu kamar. Setelah itu diukur serapannya dengan spektrofotometer UV-Vis pada panjang gelombang maksimum yang diperoleh. Total fenolat sampel ditentukan dengan rumus:

Total Fenolik $(\%)=\frac{x\left(\frac{m g}{L}\right) \times \text { vol.sampel }(\mathrm{L}) \times \mathrm{FP}}{\text { Bobot sampel }(\mathrm{mg})} \times 100 \%$

\section{Penentuan Aktivitas Antioksidan dengan Metode DPPH (IC $C_{50}$ ) (Brand dan Cuvelier, 1995)}

Ekstrak pekat sampel ditentukan aktivitas antioksidannya menggunakan metode spektrofotometri dengan pereaksi DPPH. Ekstrak sampel ditimbang sebanyak $25 \mathrm{mg}$, dimasukkan ke dalam labu ukur $25 \mathrm{ml}$, kemudian diencerkan dengan pelarut etanol sehingga didapatkan konsentrasi larutan 1000 ppm. Setelah itu dilakukan seri pengenceran untuk mendapatkan larutan 10, 30, 50, 70 dan 90 ppm. Larutan yang telah dibuat dipipet sebanyak 0,2 $\mathrm{ml}$ dan ditambahkan dengan $3,8 \mathrm{ml}$ larutan DPPH $50 \mu \mathrm{M}$. Campuran dihomogenkan dan dibiarkan selama 30 menit dalam tempat gelap. Kemudian diukur serapannya pada panjang gelombang $517 \mathrm{~nm}$. Pengujian juga dilakukan terhadap larutan DPPH. Nilai absorbansi yang diperoleh digunakan untuk menentukan \% inhibisi dengan rumus berikut:

$\%$ Inhibisi $=\frac{\text { Abs. DPPH }- \text { Abs. Sampel }}{\text { Abs. DPPH }} \times 100 \%$
Selanjutnya, dibuat kurva \% inhibisi dan ditentukan $\mathrm{IC}_{50}$ berdasarkan persamaan regresi yang diperoleh.

\section{Rancangan Penelitian/Analisis Data}

Penelitian ini dirancang menggunakan Rancangan Acak Lengkap (RAL) atau analisa of varian (ANOVA) yaitu untuk perlakuan rasio pelarut dengan 6 tingkatan rasio yaitu $2: 1 \mathrm{v} / \mathrm{b}$, (A), $3: 1 \mathrm{v} / \mathrm{b}(\mathrm{B}), 4: 1 \mathrm{v} / \mathrm{b}(\mathrm{C}), 5: 1 \mathrm{v} / \mathrm{b}$ (D), $6: 1 \mathrm{v} / \mathrm{b}(\mathrm{E})$ dan $7: 1 \mathrm{v} / \mathrm{b}(\mathrm{F})$ setiap perlakuan diulang sebanyak 3 kali sehingga terdapat 18 percobaan. Data yang diperoleh akan dianalisis dengan analisis varian, apabila terdapat perbedaan/pengaruh sangat nyata atau nyata antar perlakuan maka akan dilanjutkan dengan uji BNJ pada taraf signifikasi $1 \%$ atau $5 \%$.

\section{HASIL DAN PEMBAHASAN}

\section{Rendemen Ekstrak}

Hasil analisis ragam menunjukkan bahwa perlakuan rasio pelarut memberikan pengaruh sangat nyata terhadap rendemen ekstrak kulit buah naga merah. Hasil analisis uji lanjut BNJ $1 \%$ dan rerata rendemen ekstrak kulit buah naga pada perlakuan rasio pelarut dapat dilihat pada Gambar 1.

Gambar 1 menunjukkan bahwa rendemen ekstrak tertinggi dihasilkan pada perlakuan rasio pelarut 4:1 (v/b) yaitu $26,22 \%$ yang tidak berbeda dengan perlakuan rasio pelarut $3: 1 ; 5: 1$ dan $6: 1$ (v/b) tetapi berbeda dengan perlakuan rasio pelarut 2:1 dan 7:1 (v/b) pada uji 
lanjut $\mathrm{BNJ} 1 \%$, sedangkan rendemen ekstrak terendah dihasilkan pada perlakuan rasio pelarut $2: 1 \quad(\mathrm{v} / \mathrm{b})$ yaitu $22,66 \%$ yang berbeda dengan perlakuan rasio pelarut lainnya pada uji lanjut BNJ $1 \%$.

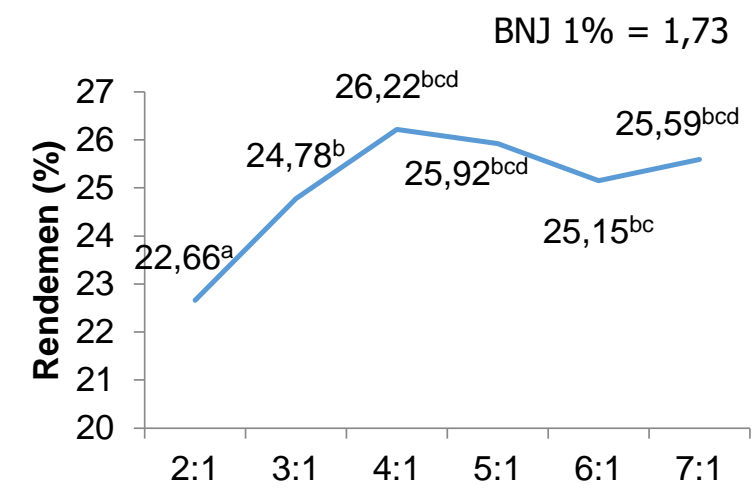

Rasio Pelarut : Kulit Buah Naga (v/b)

Keterangan : Superskrip dengan huruf yang berbeda menunjukkan perbedaan yang nyata pada uji BNJ taraf $1 \%$.

Gambar 1. Rerata rendemen ekstrak (\%) kulit buah naga pada perlakuan rasio pelarut.

Gambar 1 terlihat peningkatan rasio pelarut sampai $4: 1 \quad$ (v/b) meningkatkan rendemen ekstrak yang cenderung sebanding. Hasil penelitian ini sesuai dengan pernyataan yang dikemukakan oleh Benedicta et al. (2016), bahwa semakin banyak pelarut yang digunakan maka semakin banyak minyak yang terekstrak. Hal ini disebabkan semakin besarnya rasio pelarut terhadap sampel maka perbedaan konsentrasi antara pelarut dengan komponen yang terkandung di dalam sampel semakin tinggi. Dengan demikian rendemen ekstraksi akan semakin meningkat. Selain itu, peningkatan nilai rendemen diduga disebabkan oleh meningkatnya luas kontak sampel dengan pelarut. Hal ini diperkuat juga oleh Wulan (2001) bahwa jika jumlah pelarut terlalu kecil maka hanya sedikit pelarut yang dapat mengikat ekstrak zat terlarut.

Rifai et al. (2018) menyatakan bahwa semakin tinggi jumlah pelarut yang digunakan, maka pengeluaran senyawa target ke dalam pelarut dapat berjalan lebih optimal dan pelarut mengalami kejenuhan juga dapat dihindari. Akan tetapi, setelah jumlah pelarut dinaikkan dalam jumlah tertentu maka peningkatan senyawa terekstrak relatif kecil dan cenderung menjadi konstan.

Akan tetapi peningkatan lebih lanjut menyebabkan penurunan rendemen ekstrak (ekstrak yang dihasilkan dalam bentuk bubuk). Hal tersebut memberikan indikasi kondisi optimum ekstraksi kulit buah kakao ditinjau dari aspek rasio pelarut dengan bahan terdapat pada penggunaan rasio pelarut $4: 1(\mathrm{v} / \mathrm{b})$.

Teresa et al. (2016) menambahkan bahwa semakin banyak jumlah pelarut yang digunakan akan menyebabkan rendemen mengalami penurunan karena terjadinya keadaan kesetimbangan antara padat cair telah tercapai.

\section{Total Fenolat}

Hasil analisis ragam menunjukkan bahwa perlakuan rasio pelarut memberikan pengaruh sangat nyata terhadap total fenolat ekstrak kulit buah naga merah. Hasil analisis uji lanjut BNJ 
$1 \%$ dan rerata total fenolat ekstrak kulit buah naga merah pada perlakuan rasio pelarut dapat dilihat pada Gambar 2.

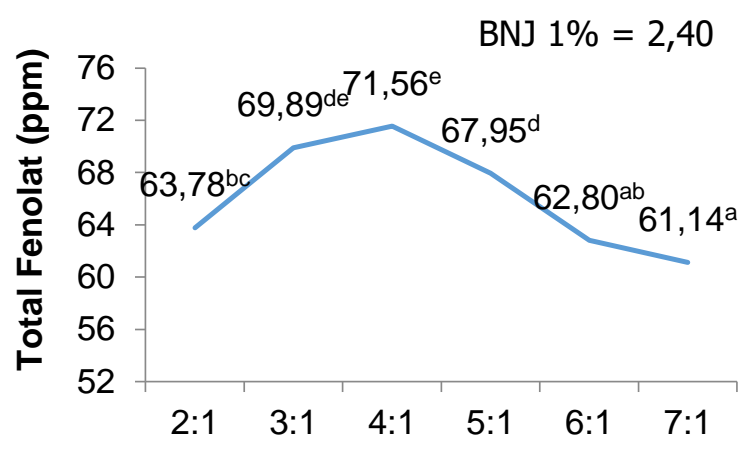

Rasio Pelarut/Kulit Buah Naga (v/b)

*Keterangan: Superskrip dengan huruf yang berbeda menunjukkan perbedaan yang nyata pada uji BNJ taraf $1 \%$.

Gambar 2. Rerata total fenolat (ppm) kulit buah naga pada perlakuan rasio pelarut.

Gambar 2 menunjukkan bahwa total fenolat tertinggi dihasilkan pada perlakuan rasio pelarut $4: 1$ (v/b) yaitu 71,56 ppm yang tidak berbeda dengan perlakuan rasio pelarut 3:1 (v/b) tetapi berbeda dengan perlakuan rasio pelarut lainnya pada uji lanjut BNJ $1 \%$, sedangkan total fenolat terendah dihasilkan pada perlakuan rasio pelarut 7:1 (v/b) yaitu 61,14 ppm yang tidak berbeda dengan perlakuan rasio pelarut 6:1 (v/b) tetapi berbeda dengan perlakuan rasio pelarut lainnya pada uji lanjut BNJ $1 \%$.

Hasil penelitian menunjukkan bahwa peningkatan rasio pelarut sampai 4:1 (v/b) meningkatkan kandungan senyawa total fenolat kulit buah naga. Hal tersebut memberikan keterangan kelarutan senyawa fenolat dalam kulit buah naga meningkat dengan meningkatnya penggunaan rasio pelarut. Pada Gambar 2 juga memperlihatkan pola perubahan total fenolat kulit buah naga terhadap perlakuan rasio pelarut sama dengan pola perubahan rendemen ekstrak (Gambar 1).

Hal ini sesuai dengan hasil penelitian Handayani et al. (2016) bahwa semakin besar jumlah rasio pelarut yang digunakan menyebabkan total fenol yang dihasilkan semakin tinggi dan meningkat dan terdapat pengaruh yang nyata antar parameter, karena semakin besar jumlah rasio pelarut yang digunakan maka semakin besar kemampuan pelarut untuk melarutkan komponen senyawa yang terdapat dalam bahan sehingga semakin banyak komponen senyawa yang dapat terekstrak oleh pelarut tersebut.

Hal ini menunjukkan bahwa rasio pelarut 4:1 (v/b) lebih efektif dalam menghasilkan kandungan senyawa fenol dalam ekstrak kulit buah naga dibanding perlakuan lainnya. Hal ini kemungkinan disebabkan karena sifat dari senyawa fenol yang larut dalam pelarut organik atau pelarut yang sifatnya polar, dimana etanol merupakan pelarut organik dengan sifat polar yang dapat melarutkan dengan baik kandungan senyawa fenol dalam bahan sehingga semakin besar perbandingannya semakin besar juga terjadinya kontak antara partikel serbuk dengan pelarut sehingga senyawa fenol semakin banyak yang terekstrak. 
Pada perlakuan rasio pelarut $4: 1$ (v/b) juga diduga telah mencapai titik optimumnya, sehingga ketika volume pelarut ditambahkan menjadi rasio 5:1 hingga 7:1 (v/b), maka tidak memberikan pengaruh dalam proses ekstraksi senyawa fenolat yang ditargetkan. Menurut Handayani et al. (2016) bahwa komponen bahan yang terekstrak akan terus meningkat hingga larutan menjadi jenuh, setelah melewati titik jenuh larutan, tidak akan terjadi peningkatan hasil ekstraksi dengan penambahan pelarut.

Rasio pelarut yang lebih kecil dimungkinkan dapat teruapkan sempurna pada saat proses pemisahan pelarut. Tetapi tidak terjadi pada rasio pelarut yang lebih besar. Dimungkinkan masih terdapat pelarut di dalam hasil ekstrak tersebut yang dapat mengakibatkan terjadinya hidrolisis senyawa fenol. Sehingga tidak teranalisis sebagai senyawa fenol. Maka dari itu, semakin tinggi rasio pelarut, semakin rendah total fenol (Maligan et al., 2015).

\section{Aktivitas Antioksidan (Nilai $I_{50}$ )}

Menurut Molyneux (2004) pada penelitiannya menyatakan bahwa aktivitas antioksidan diukur dari nilai $\mathrm{IC}_{50}$, yang dinyatakan pada Tabel 1 . Nilai $I_{50}$ berbanding terbalik dengan aktivitas antioksidan. Semakin rendah nilai $I_{50}$ maka akan semakin baik aktivitas antioksidannya.
Tabel 1 Nilai $\mathrm{IC}_{50}$ terhadap aktivitas antioksidan

\begin{tabular}{c|c}
\hline Aktivitas Antioksidan & Nilai IC50 $(\mathrm{ppm})$ \\
\hline Sangat Kuat & $<50$ \\
Kuat & $50-100$ \\
Sedang & $100-200$ \\
Lemah & $>200$
\end{tabular}

Hasil analisis ragam menunjukkan bahwa perlakuan rasio pelarut memberikan pengaruh sangat nyata terhadap aktivitas antioksidan (Nilai IC50) ekstrak kulit buah naga merah. Hasil analisis uji lanjut BNJ 1\% dan rerata nilai IC50 ekstrak kulit buah naga merah pada perlakuan rasio pelarut dapat dilihat pada Gambar 3.

BNJ $1 \%=1,49$

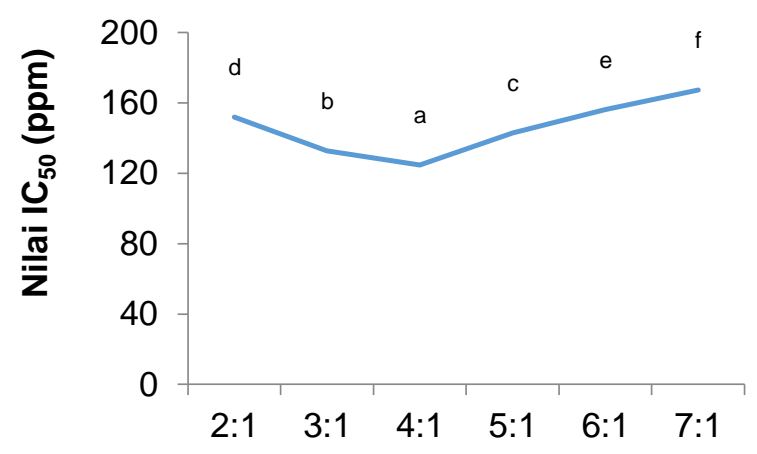

Rasio Pelarut/Kulit Buah Naga (v/b)

*Keterangan: Superskrip dengan huruf yang berbeda menunjukkan perbedaan yang nyata pada uji BNJ taraf $1 \%$.

Gambar 3. Rerata nilai $\mathrm{IC}_{50}$ (ppm) kulit buah naga pada perlakuan rasio pelarut.

Gambar 3 menunjukkan bahwa nilai $\quad \mathrm{IC}_{50}$ tertinggi dihasilkan pada perlakuan rasio pelarut $4: 1$ (v/b) yaitu 124,62 ppm yang berbeda dengan perlakuan rasio pelarut lainnya pada uji lanjut BNJ $1 \%$, sedangkan nilai $I_{50}$ 
terendah dihasilkan pada perlakuan rasio pelarut $7: 1 \quad(\mathrm{v} / \mathrm{b})$ yaitu 167,49 yang berbeda dengan perlakuan rasio pelarut lainnya pada uji lanjut BNJ $1 \%$.

Dari data diatas dapat dilihat bahwa semakin kecil nilai $\mathrm{IC}_{50}$ maka senyawa tersebut memiliki keefektifan dalam menangkap radikal bebas. Novita et al. (2016) menyatakan bahwa nilai $I_{50}$ menunjukkan kemampuan suatu antioksidan untuk meredam sebanyak $50 \%$ radikal bebas. Nilai $\mathrm{IC}_{50}$ yang semakin kecil menunjukkan semakin tingginya aktivitas antioksidan. Hal ini menunjukkan bahwa ekstraksi menggunakan rasio pelarut 4:1 (v/b) merupakan sampel yang memiliki aktivitas antioksidan paling tinggi dengan menggunakan metode DPPH ini. Berdasarkan penggolongan kekuatan aktivitas antioksidan (Molyneux, 2004), rasio pelarut 2:1 sampai 7:1 (v/b) memliki aktivitas antioksidan yang sedang karena diperoleh nilai IC50 100 - 200 ppm.

Semakin besar perbandingan antara sampel dengan pelarut, dan semakin lama waktu ekstraksi, aktivitas antioksidan yang dihasilkan semakin rendah (Yeni et al., 2014). Hal ini dapat disebabkan pada rasio sampel besar, konsentrasi larutan sudah mendekati titik equilibrium, senyawa fenolik yang terdapat dalam permukaan gambir menjadi sulit dapat terekstrak lagi dan ketika rasio sampel dan pelarut kecil, waktu yang dibutuhkan untuk mencapai titik equilibrium lebih lama dan konsentrasi fenolik dalam cairan menjadi sangat encer sehingga antioksidan yang dihasilkan semakin rendah ( $\mathrm{IC}_{50}$ besar) (Yeni et al., 2014).

\section{KESIMPULAN}

Berdasarkan hasil penelitian yang telah dilakukan maka dapat disimpulkan bahwa rasio pelarut berpengaruh sangat nyata terhadap rendemen ekstrak, total fenolat dan nilai $I_{50}$ ekstrak kulit buah naga merah. Rasio pelarut 4:1 (v/b) merupakan rasio pelarut terbaik untuk mengekstrak kulit buah naga merah karena memiliki rendemen ekstrak $(26,22 \%)$, total fenolat (71,56 ppm) dan aktivitas antioksidan (nilai $\left.\mathrm{IC}_{50}\right)(124,62$ ppm) tertinggi atau terbaik.

\section{UCAPAN TERIMA KASIH}

Penulis mengucapkan terima kasih kepada Institusi Fakultas Pertanian Universitas Tadulako yang telah memberikan dana penelitian melalui skema penelitian dosen pemula dan kepada Dewi Indriany, S.Si selaku laboran MIPA Fakultas MIPA Universitas Tadulako yang telah membantu penulis dalam melakukan penelitian.

\section{DAFTAR PUSTAKA}

Benedicta, N. O., Zain, S., Nurjanah, S., Widyasanti, A., dan Putri, S. H. 2016. Pengaruh Rasio Bunga Dengan Pelarut Terhadap Rendemen Dan Mutu Minyak Melati (Jasminum sambac) Menggunakan Metode Ekstraksi Pelarut Menguap (Solvent Extraction). Jurnal Teknotan, 10(2): 44-50. 
Brand Williams., and W. Cuvelier, M.E. 1995. Use of a free radical method to evaluate antioksidant activity. Food science and technology, 28 (1): $25-30$

Folin, Octo., and Ciocalteu, Vintila, 1944, On Tyrosine and Tryptophane Determinations in Proteins, Jour.Bio.Chem., 73 : 627-650, 1927, in. Todd-Sanford, 10, 412.

Handayani, H., Sriherfyna, F. H., \& Yunianta. 2016. Ekstraksi Antioksidan Daun Sirsak Metode Ultrasonic Bath (Kajian Rasio Bahan : Pelarut Dan Lama Ekstraksi). Jurnal Pangan dan Agroindustri, 4(1): 262-272.

Handayani, P.A., dan Rahmawati, A. 2012, Pemanfaatan Kulit Buah Naga (Dragon Fruit) sebagai Bahan Pewarna Alami Makanan Pengganti Pewarna Sintetis. Jurnal Bahan Alam Terbarukan, 1(2): 1924.

Harjanti, R. S. 2016. Optimasi Pengambilan Antosianin dari Kulit Buah Naga Merah (Hylocereus polyrhizus) Sebagai Pewarna Alami pada Makanan. Chemica, 3(2): 39-45

Hernani, Marwati, T., dan Winarti, C. 2007. Pemilihan Pelarut Pada Pemurnian Ekstrak Lengkuas (Alpinia galanga) Secara Ekstraksi. Jurnal Pascapanen, 4(1): 1-8.

Jayanudin, Lestari, A. Z., dan Nurbayanti, F. 2014. Pengaruh Suhu Dan Rasio Pelarut Ekstraksi Terhadap Rendemen Dan Viskositas Natrium Alginat Dari Rumput Laut Cokelat (Sargassum sp). Jurnal Integrasi Proses, 5(1): 51.

Lestari, P. P., Kusrini, D., dan Anam, K. 2014. Anthocyanin Identification of Methanol-HCl Extract Active Fraction in Rosella (Hibiscus Sabdariffa. L) and Its Potential as
Xanthine Oxidase Inhibitor. Jurnal Sains dan Matematika, 22(3): 7278.

Maligan, J. M., Marditia, A. P., dan Putri, W. D. 2015. Analisis Senyawa Bioaktif Ekstrak Mikroalga Laut Tetraselmis chuii Sebagai Sumber Antioksidan Alami. J.REKAPANGAN, 9(2): 1-10.

Molyneux, P. 2004. The use of the stable free radical diphenylpicrylhydrazyl (DPPH) for estimating antioxidant activity. Songklanakarin Journal of Science and Technology, 26(November 2003), 211-219.

Novita, M., Sulaiman, M., dan Yura, S. 2016. Pengaruh Jenis Pelarut terhadap Aktivitas Antioksidan dan Kandungan Fenol Beberapa Jenis Bayam dan Sayuran Lain. Jurnal IImiah Mahasiswa Pertanian Unsyiah, 1(1): 935-940.

RIfai, G., Widarta, I. R., dan Nocianitri, K. A. 2018. Pengaruh Jenis Pelarut dan Rasio Bahan dengan Pelarut Terhadap Kandungan Senyawa Fenolik dan Aktivitas Antioksidan Ekstrak Biji Alpukat (Persea americana Mill .). Jurnal ITEPA, 7(2): 22-32.

Rivai, H., Putra, R. Y., dan Krisyanella. 2012. Penentuan Pengaruh Jenis Pelarut Pengekstrak Terhadap Perolehan Kadar Senyawa Fenolat Dan Aktifitas Antioksidan Dari Daun Jambu Biji (Psidium). 4(1): 16-23.

Santoso, A. F., dan Fibrianto, K. 2017. Pengaruh Ekstrak Kulit Buah Naga Merah (Hylocereus Polyrhizus) Terhadap Kualitas Sosis Ayam: Tinjauan Pustaka. Jurnal Pangan dan Agroindustri, 5(4): 92-96.

Stintzing, F.C., Scheibe, A. And Carle, R. 2002. Betacyanin in Fruit from Red Purple Pitaya (Hylocereus Polyrhizus) (Weber) Brintton and 
Rose. Food Chemistry, 77: 101106.

Teresa, Y., Hidayati, N., dan Nugrahani, R. A. 2016. Pengaruh Rasio Pelarut Kloroform (v/v) Pada Ekstraksi Trimiristin Biji Pala (Myristica fragrans HOUTT). Teknik Kimia, 2: 3-6.

Wu, L.C., Hsu, H.W., Chen, Y.C., Chiu, C.C., Lin, Y.I. And Ho, J.A. 2006. Antioxidant and Antiproliferative Activities of Red Pitaya. Food Chemlstry, 95: 319 - 327.

Wulan, S. N. 2013. Kemungkinan Pemanfaatan Limbah Kulit Buah Kakao (Theobroma cacao, L)
Sebagai Sumber Zat Pewarna ( $\beta$ Karoten). Jurnal Teknologi Pertanian, 53(9): 1689-1699.

Yeni, G., Sa'id, E., Syamsu, K., dan Mardliyati, E. 2014. Penentuan Kondisi Terbaik Ekstraksi Antioksidan Dari Gambir Menggunakan Metode Permukaan Respon. Jurnal Litbang Industri, 4(1): 39.

Yuswi, N. C. (2017). Ekstraksi Antioksidan Bawang Dayak (Eleutherine palmifolia) Dengan Metode Ultrasonic Bath (Kajian Jenis Pelarut Dan Lama Ekstraksi). Jurnal Pangan dan Agroindustri, 5(1): 71-78. 